\title{
The Cost of Capital of Cross-Listed Firms
}

\author{
Kees G. Koedijk, Mathijs A. van Dijk
}

\begin{tabular}{|l|l|}
\hline \multicolumn{2}{|l|}{ ERIM REPORT SERIES RESEARCH IN MANAGEMENT } \\
\hline ERIM Report Series reference number & ERS-2002-99-F\&A \\
\hline Publication status / version & October 2002 \\
\hline Number of pages & 37 \\
\hline Email address corresponding author & c.koedij@@fbk.eur.nl, madijk@fbk.eur.nl \\
\hline Address & Erasmus Research Institute of Management (ERIM) \\
& Rotterdam School of Management / Faculteit Bedrijfskunde \\
& Erasmus Universiteit Rotterdam \\
& PoBox 1738 \\
& 3000 DR Rotterdam, The Netherlands \\
& Phone: \# 31-(0) 10-408 1182 \\
& Fax: \# 31-(0) 10-408 9640 \\
& Email: info@erim.eur.nl \\
& Internet: $\quad$ www.erim.eur.nl \\
\hline
\end{tabular}

Bibliographic data and classifications of all the ERIM reports are also available on the ERIM website: www.erim.eur.nl 


\title{
ERASMUS RESEARCH INSTITUTE OF MANAGEMENT
}

\author{
REPORT SERIES
}

RESEARCH IN MANAGEMENT

\begin{tabular}{|c|c|c|}
\hline \multicolumn{3}{|c|}{ BIBLIOGRAPHIC DATA AND CLASSIFICATIONS } \\
\hline Abstract & \multicolumn{2}{|c|}{$\begin{array}{l}\text { This paper analyzes the cost of capital of firms with foreign equity listings. Our purpose is to } \\
\text { shed light on the question whether international and domestic asset pricing models yield a } \\
\text { different estimate of the cost of capital for cross-listed stocks. We distinguish between (i) the } \\
\text { multifactor ICAPM of Solnik (1983) and Sercu (1980) including both the global market portfolio } \\
\text { and exchange rate risk premia, and (ii) the single factor domestic CAPM. We test for the } \\
\text { significance of the cost of capital differential in a sample of } 336 \text { cross-listed stocks from nine } \\
\text { countries in the period 1980-1999. Our hypothesis is that the cost of capital differential is } \\
\text { substantial for firms with international listings, as these are often large multinationals with a } \\
\text { strong international orientation. We find that the asset pricing models yield a significantly } \\
\text { different estimate of the cost of capital for only } 12 \text { percent of the cross-listed companies. The } \\
\text { size of the cost of capital differential is around } 50 \text { basis points for the U.S., } 80 \text { basis points for } \\
\text { the U.K., and } 100 \text { basis points for France. }\end{array}$} \\
\hline \multirow{4}{*}{$\begin{array}{l}\text { Library of Congress } \\
\text { Classification } \\
\text { (LCC) }\end{array}$} & 5001-6182 & Business \\
\hline & $5601-5689$ & Accountancy, Bookkeeping \\
\hline & $4001-4280.7$ & Finance Management, Business Finance, Corporation Finance \\
\hline & HG 4028.C4 & Capital investments (Financial management) \\
\hline \multirow{5}{*}{$\begin{array}{l}\text { Journal of Economic } \\
\text { Literature } \\
\text { (JEL) }\end{array}$} & M & Business Administration and Business Economics \\
\hline & $\begin{array}{l}\text { M } 41 \\
\text { G } 3\end{array}$ & $\begin{array}{l}\text { Accounting } \\
\text { Corporate Finance and Governance }\end{array}$ \\
\hline & G 15 & International Financial Markets \\
\hline & G 31 & Capital Budgeting; Investment Policy \\
\hline & F 31 & Foreign Exchange \\
\hline \multirow{4}{*}{$\begin{array}{l}\text { European Business Schools } \\
\text { Library Group } \\
\text { (EBSLG) }\end{array}$} & $85 \mathrm{~A}$ & Business General \\
\hline & $225 \mathrm{~A}$ & Accounting General \\
\hline & $220 \mathrm{~A}$ & Financial Management \\
\hline & $220 \mathrm{~F}$ & Financial markets \\
\hline \multicolumn{3}{|c|}{ Gemeenschappelijke Onderwerpsontsluiting (GOO) } \\
\hline \multirow[t]{3}{*}{ Classification GOO } & 85.00 & Bedrijfskunde, Organisatiekunde: algemeen \\
\hline & 85.25 & Accounting \\
\hline & 85.30 & Financieel management, financiering \\
\hline \multirow[t]{3}{*}{ Keywords GOO } & \multicolumn{2}{|c|}{ Bedrijfskunde / Bedrijfseconomie } \\
\hline & \multicolumn{2}{|c|}{ Accountancy, financieel management, bedrijffinanciering, besliskunde } \\
\hline & \multicolumn{2}{|c|}{ Kapitaalmarkt, Wisselkoersen, portfolio-analyse } \\
\hline Free keywords & \multicolumn{2}{|c|}{ Cross-listings, cost of equity capital, foreign exchange exposure } \\
\hline
\end{tabular}




\title{
The Cost of Capital of Cross-Listed Firms
}

\author{
Kees G. Koedijk \\ Erasmus University Rotterdam and CEPR \\ Mathijs A. van Dijk \\ Erasmus University Rotterdam
}

This version: October 2002

\section{Correspondence}

Kees G. Koedijk

Department of Financial Management (Room F4-21)

Erasmus University Rotterdam

PO Box 1738

3000 DR Rotterdam

THE NETHERLANDS

Phone: +31 104082748

Fax : +31 104089017

E-mail: c.koedijk@fbk.eur.nl

We thank Peter Roosenboom and seminar participants at Erasmus University Rotterdam for helpful comments. We are grateful to Richard Speetjens for valuable research assistance. Any remaining errors are our own. 


\title{
The Cost of Capital of Cross-Listed Firms
}

\begin{abstract}
This paper analyzes the cost of capital of firms with foreign equity listings. Our purpose is to shed light on the question whether international and domestic asset pricing models yield a different estimate of the cost of capital for cross-listed stocks. We distinguish between (i) the multifactor ICAPM of Solnik (1983) and Sercu (1980) including both the global market portfolio and exchange rate risk premia, and (ii) the single factor domestic CAPM. We test for the significance of the cost of capital differential in a sample of 336 cross-listed stocks from nine countries in the period 1980-1999. Our hypothesis is that the cost of capital differential is substantial for firms with international listings, as these are often large multinationals with a strong international orientation. We find that the asset pricing models yield a significantly different estimate of the cost of capital for only 12 percent of the cross-listed companies. The size of the cost of capital differential is around 50 basis points for the U.S., 80 basis points for the U.K., and 100 basis points for France.
\end{abstract}

\section{Keywords}

Cross-listings, cost of equity capital, foreign exchange exposure

\section{JEL subject codes}

G15, G31, F31 


\section{Introduction}

As many companies have become considerably more internationally oriented over the past decades, foreign equity listings have gained importance as a strategic management tool. The number of international cross-listings in the U.S. has increased in recent years. Since 1993, the total number of non-U.S. listed companies at the NYSE has more than quadrupled to 471 as of October 14, 2002. The number of international stocks at Nasdaq has increased from 261 at the end of 1992 to more than 385 at October 14, 2002 (with a peak of over 450 in August 2001). Since 1996, the number of cross-listed firms at the AMEX has about doubled to 52 as of October 14, 2002.

The literature on international cross-listings focuses on three main issues. First, many studies have examined the effects of a cross-border listing of a stock in terms of excess returns, liquidity, and risk. Foerster and Karolyi (1993) investigate Canadian stocks that list in the U.S. and find a positive pre-listing abnormal return, while the 100-day post-listing abnormal return is negative. The liquidity of the stocks increases and the betas decrease on average. Werner and Kleidon (1996) also find that liquidity increases for a sample of U.K stocks that have a cross-listing at the NYSE. The authors find no effect for the risk of the stocks. Jorion and Schwartz (1986) compare the cost of capital and the risk of 94 Canadian stocks that are dually listed in the U.S. with a benchmark sample of 655 Canadian stocks not listed at an exchange in the U.S. They find that the cross-listed companies have a lower cost of capital, but a higher sensitivity to U.S. market risk than the benchmark firms. More recently, Doukas and Switzer (2000) find a significantly positive stock market reaction to the announcement of a listing in the U.S. by 79 Canadian firms in the period 1977-1997. This is consistent with the hypothesis that international listings lead to a decrease in the risk premium of firms operating in mildly segmented markets. In an extensive survey of studies on crosslistings, Karolyi (1998) concludes that the evidence indicates a favorable short-term stock price reaction to the listing, an improvement in liquidity, and a considerably lower cost of equity capital. The evidence on longer term post-listing stock price performance is mixed.

Second, the characteristics of companies that list their shares abroad have been studied extensively, as well as the motivations for cross-listing their stock at a foreign exchange. Saudagaran (1988) examines a sample of 223 companies that obtain a dual listing in Canada, Europe, Japan, or the U.S. and finds that large firms with a high percentage of sales abroad are relatively likely to list abroad. Similarly, Pagano, Röell, and Zechner (2002) find that companies that list abroad are relatively large and have a high level of foreign sales and R\&D 
spending. Biddle and Saudagaran (1989) conclude that firms are relatively unlikely to list at overseas exchanges with stricter disclosure regulations than the home market. Karolyi (1998) reviews the recent evidence and concludes that stringent disclosure requirements are the main obstacle to overseas listings. Fuerst (1998), on the other hand, argues that companies could use a cross-listing at an exchange with strict regulations for signaling quality.

Third, a number of recent studies employ high-frequency data of cross-listed securities on different exchanges to analyze price discovery of internationally-traded firms. Grammig, Melvin, and Schlag (2000) examine intra-day quote data of three large German firms at the Frankfurt Stock Exchange and the NYSE. Their results indicate that price discovery mainly occurs in the home market. Adjustment to exchange rate shocks (e.g. for maintaining the law of one price) predominantly takes place on the NYSE, however. Eun and Sabherwal (2002) study price discovery for a sample 62 Canadian firms listed on the Toronto Stock Exchange and either the NYSE, the Nasdaq or the AMEX. They find that while price discovery primarily occurs on the Toronto Stock Exchange for most firms, the U.S. market's contribution to price discovery is dominant for several stocks. The contribution of the U.S. exchange is positively related to the U.S. share of trading and negatively related to the relative spread size in the U.S.

We take another angle and focus on the cost of capital of interlisted stocks. The purpose of this paper is to shed light on the question whether international and domestic asset pricing models lead to a different estimate of the cost of capital for a firm with at least one listing abroad. In a recent study, Stulz (1995) derives an expression for the difference in the estimation of a firm's beta when computed with the domestic CAPM as compared to the single factor ICAPM of Grauer, Litzenberger, and Stehle (1976). The estimated cost of capital differential is an affine function of this so-called "pricing error". Stulz uses data on the Swiss multinational Nestlé and finds a substantial pricing error. He concludes that the domestic CAPM may well provide an incorrect estimate of the cost of capital for firms in small economies in general. Koedijk, Kool, Schotman, and van Dijk (2001) derive statistical tests for the pricing error between the domestic CAPM and the multifactor ICAPM of Solnik (1983) and Sercu (1980) including both the global market portfolio and exchange rate risk premia. 
The issue examined in this paper is illustrated in figure 1. The multifactor ICAPM is the maintained hypothesis. $\square_{A}$ pricing error arises for an individual firm if the "direct" approach of computing the cost of equity capital through the multifactor ICAPM leads to a different result than the "indirect" approach of using the domestic CAPM.

Our hypothesis is that firms with at least one international listing exhibit a large pricing error. As mentioned above, several studies have shown that companies with overseas listings have a large market capitalization and a high percentage of sales abroad. These firms show a clear international orientation and are therefore be expected to exhibit substantial exposure to the global risk factors (including exchange rates). This exposure cannot in general be captured in the international pricing of the local stock market index. Consequently, the direct estimate of the cost of capital of cross-listed companies may well substantially deviate from the indirect estimate.

We analyze a sample of 336 interlisted stocks from nine different countries over the sample period 1980:02-1999:06. We find a significant pricing error between the domestic CAPM and the multifactor ICAPM for only 12 percent of the firms in our sample. The absolute difference in the cost of capital for cross-listed companies amounts to about 50 basis points for the U.S., 55 basis points for Germany, 90 basis points for Japan and 80 basis points for the U.K. Hence, we find limited evidence supporting our hypothesis that the pricing error is significant for firms with international cross-listings. We show that these results are likely to be due to strong country factors in the data, consistent with the evidence of Heston and Rouwenhorst (1994) and Griffin and Karolyi (1998). A potential explanation for this finding is a lack of real capital market integration (as opposed to financial capital market integration) caused by cyclical, structural, and institutional country-specific factors. De Ménil (1999) presents evidence that these country-specific factors play a significant role in explaining corporate returns in Europe. Our evidence suggests that investors could exploit the observed differences between countries for the purpose of portfolio diversification.

We compare our results for companies with foreign listings to a benchmark sample of 2,957 companies that do not have international listings. Around 4 percent of these "domestic" firms show a significant pricing error. The estimated cost of capital differential amounts to 80 basis points on average for domestic stocks.

1 A number of recent papers do not reject the joint hypothesis of the multifactor ICAPM including currency risk premia and capital market integration for a variety of industrialized countries. We refer to section 2 for a discussion of the literature on this issue. 
The paper is organized as follows. In section 2 we briefly review the CAPM, the ICAPM, and the pricing error testing methodology. Section 3 provides a description of the data. We discuss our empirical results for interlisted stocks and our benchmark sample of domestic stocks in section 4. Section 5 summarizes and concludes.

\section{Methodology}

In this section we discuss tests to evaluate whether the domestic CAPM yields a significantly different cost of capital than the multifactor ICAPM. The basic methodology is taken from Koedijk, Kool, Schotman, and van Dijk (2001). In the Solnik-Sercu version of the multifactor ICAPM, the systematic risk factors are the global market portfolio and exchange rate factors. Assume a world with $N+1$ countries (currencies). The ICAPM has $N+1$ systematic risk factors: the global market portfolio and $N$ exchange rates. The model can be expressed as

$$
E\left[R_{i}\right]=r_{0}+E\left[R_{G}-r_{0}\right] d_{i 1}+E\left[S+r-\imath r_{0}\right]^{\prime} d_{i 2},
$$

where $R_{i}$ and $R_{G}$ are the return of asset $i$ and the global market, respectively, expressed in the numeraire currency. As the numeraire currency we choose the home currency 0 of asset $i$. $S$ represents the vector of nominal exchange rate returns of the other $l=1, \ldots, N$ countries against currency 0 . The vector $r$ denotes the nominal returns on the risk-free asset in country $l$ $(l=1, \ldots, N) . r_{0}$ is the risk-free rate in the numeraire (home) country, and $l$ is a vector of ones. For a derivation of equation (1) we refer to Sercu and Uppal (1995). The global market beta and the exchange rate betas are defined as the regression coefficients $d_{i 1}$ and $d_{i 2}$ in

$$
R_{i}=\alpha_{1 i}+Z^{\prime} d_{i}+u_{i}=\alpha_{1 i}+R_{G} d_{i 1}+S^{\prime} d_{i 2}+u_{i},
$$

where $Z^{\prime}=\left[R_{G}, S^{\prime}\right]$ and $\alpha_{1 i}=r_{0}\left(1-d_{i 1}\right)+\left(r-\imath r_{0}\right)^{\prime} d_{i 2}$ is assumed to be constant. The specific risk $u_{i}$ is orthogonal to $Z$. This version of the ICAPM is the maintained hypothesis for the rest of this paper.

In order to estimate $d_{i}$ we assume that the regression parameters are constant within a particular sample period. The risk premia on the global market and the currency factors may be time varying though. 2 Our empirical tests will be formulated in terms of hypotheses on the factor loadings $d_{i}$ for individual stocks relative to the global factors.

We follow Stulz (1995) and consider the domestic CAPM as an alternative model

$$
E\left[R_{i}\right]=r_{0}+E\left[R_{L}-r_{0}\right] b_{i},
$$

2 See for example Dumas and Solnik (1995). 
where $R_{L}$ is the return of the local market index expressed in the numeraire currency 0 . The beta of the CAPM can be estimated in the regression

$$
R_{i}=\alpha_{2 i}+R_{L} b_{i}+e_{i},
$$

The domestic CAPM posits a different decomposition into systematic and specific risk than the ICAPM. In order to compare the two models, we need to relate $R_{L}$ to the global factors $Z$. Since equation (2) applies to every individual stock, it also applies to the local market portfolio of every country. Applying (2) to $R_{L}$ we get

$$
R_{L}=\alpha_{L}+Z^{\prime} d_{L}+u_{L}
$$

where $u_{L}$ is orthogonal to $Z$. Substituting equation (5) into (4) yields

$$
R_{i}=\alpha_{3 i}+Z^{\prime} d_{L} b_{i}+u_{L} b_{i}+e_{i},
$$

where $\alpha_{3 i}=\alpha_{2 i}+b_{i} \alpha_{L}$. Equations (2) and (6) lead to the same decomposition of systematic and specific risk if the local specific risk $e_{i}$ in equation (4) is orthogonal to $Z$. In that case, the composite specific risk term $u_{L} b_{i}+e_{i}$ is orthogonal to $Z$ and equations (2) and (6) are identical. But then the parameters in equations (2) and (6) must be the same too, implying

$$
d_{i}=d_{L} b_{i}
$$

If the restrictions in equation (7) hold, no pricing error results from using the domestic CAPM instead of the ICAPM. ${ }^{3}$ We call a test for this null-hypothesis a pricing error test. It tests the orthogonality between the global factors and the residuals from the domestic CAPM regression (4). A simple way to implement the test is to add the global instruments $Z$ to the domestic CAPM regression,

$$
R_{i}=\alpha_{4 i}+R_{L} \beta_{i}+Z^{\prime} \delta_{i}+\zeta_{i} .
$$

Under $\mathrm{H}_{0}: \delta_{i}=0$, we can see that $\alpha_{4 i}=\alpha_{2 i}, \beta_{i}=b_{i}$, and $\zeta_{i}=e_{i}$. The test for the null-hypothesis $\delta_{i}=0$ is called the "Pricing Error" test. It tests the orthogonality between the global factors and the residuals from the domestic CAPM regression (4). If the restriction holds, risk that is specific according to the domestic CAPM does not contain additional systematic risk related to the global factors. Consequently, the domestic market portfolio contains all the information that is relevant to price assets. On the other hand, if risk that is diversifiable domestically contains risk that is systematic in the world market, the domestic CAPM incorrectly ignores such risk. The ICAPM will require a risk premium, however. In that case, the domestic CAPM leads to a different cost of capital than the ICAPM.

3 We assume that the parameter restriction $\alpha_{1 i}=\alpha_{2 i}+b_{i} \alpha_{L}$ holds. 
Rejection of (7) can be due to either the condition on the beta of the global market portfolio $\left(d_{i 1}=d_{L 1} b_{i}\right)$, the exchange rate betas $\left(d_{i 2}=d_{L 2} b_{i}\right)$, or both. If rejection occurs because of violation of the exchange rate restrictions $d_{i 2}=d_{L 2} b_{i}$, the impact on the estimated cost of capital might nevertheless be zero if required foreign exchange risk premia $\mathrm{E}\left[S+r-\imath r_{0}\right]$ are zero. Therefore, whether only the first restriction in equation (7) is rejected within the framework of the multifactor ICAPM is of interest under the assumption that exchange rate risk premia are zero. In appendix A we show that the pricing error vector $p_{i}=d_{L} b_{i}-d_{i}$ can be written as a linear combination of the parameter $\delta_{i}$ in equation (8)

$$
p_{i}=\left(\mathrm{I}+\frac{d_{L} d_{L}^{\prime} \Omega}{\sigma_{L}^{2}}\right)^{-1} \delta_{i}=\Lambda \delta_{i},
$$

where $\Omega$ is the covariance matrix of $Z$ and $\sigma_{L}^{2}$ is the variance of residuals $u_{L}$ in equation (5). We test the null-hypothesis that the first element of $p_{i}$ is equal to zero. We call this the "Global Beta" test. If the null-hypothesis is rejected, the direct ICAPM beta $d_{i 1}$ will differ significantly from the indirect beta $d_{L 1} b_{i}$.

An important assumption in our analysis is that the multifactor ICAPM holds for every individual stock and thus for the domestic market portfolio of every country. Hence, our tests can be interpreted as an examination of the issue whether the domestic CAPM will produce an adequate estimate of a firm's cost of capital when the multifactor ICAPM is the correct model. The issue of capital market integration has received a lot of attention in the recent finance literature. Jorion and Schwartz (1986) find that the unconditional single factor ICAPM does not accurately describe fluctuations in Canadian stock returns for the period from 1968 through 1982. They use a North American market index as the only priced risk factor. This can be interpreted as evidence against integration of the Canadian and U.S. equity markets. Harvey (1991) tests whether the conditional single factor ICAPM is consistent with the behavior of stock returns in 17 countries over the period 1969-1989. Harvey concludes that the hypothesis of conditional mean variance efficiency cannot be rejected for most countries. The model's restrictions are rejected for Japan at the 5\% level and for the U.S. at the $10 \%$ level, however.

As is noted by e.g. Bekaert and Harvey (1995), it is difficult to interpret the joint hypotheses tested in these studies. Bekaert and Harvey (1995, p. 404) formulate the intricacy of interpreting Harvey's (1991) results as follows: "Is the rejection in Japan a result of using a one factor model, a function of Japanese stock prices deviating from their fundamental values (inefficiency), or an implication of imposing the null hypothesis of complete market 
integration?". More recently, De Santis and Gérard (1997) present evidence that global market risk is equally priced across countries in a conditional framework. The paper analyzes the world's eight largest equity markets over the period 1970-1994. The hypothesis that the price of country-specific risk is not different from zero is not rejected. This is consistent with the single factor ICAPM and with international capital market integration.

Several studies examine market integration in the context of a multifactor ICAPM, in which the assumption of purchasing power parity is relaxed. Dumas and Solnik (1995) reject the hypothesis that currency risk is not priced for Germany, Japan, the United Kingdom, and the United States in the period January 1970 to December 1991. They argue that the conditional multifactor ICAPM dominates the single factor ICAPM. De Santis and Gérard (1998) directly test the restrictions imposed by the conditional multifactor ICAPM using stock market indices of Germany, Japan, the United Kingdom, and the United States in the period 1973-1994. Their specification of the international asset pricing models includes three currency risk factors related to the Deutsche mark, the Japanese yen, and the British pound. The analysis provides strong evidence for a model that includes both global market risk and currency risk factors. Country-specific risk is not priced, which suggests markets are integrated. Vassalou (2000) finds that foreign exchange rate risk is priced in the returns of individual securities from 10 countries in the period 1973-1990.

The issue whether capital markets in Japan and the U.S. can be considered integrated has been extensively studied in the literature. Using an unconditional multifactor ICAPM (without currency risk factors), Gultekin, Gultekin, and Penati (1989) do not find evidence of segmentation between the Japanese and the U.S. markets in the four years after the major liberalization in the Japanese capital market in December 1980. Campbell and Hamao (1992) find some evidence for common movements in Japanese and U.S. stock returns, which suggests at least partial integration. However, stock returns are not well explained by a constant-beta single factor ICAPM.

Evaluating tests for capital market integration is difficult. Rejections of the integration hypothesis for Japan and the U.S. in early studies may reflect the fact that these studies employ single factor versions of the ICAPM and consequently ignore deviations from PPP. Later studies that relax the assumption of absolute PPP, e.g. De Santis and Gérard (1998) and Vassalou (2000), do find evidence in favor of the joint hypothesis of the multifactor ICAPM and market integration for a variety of countries over a recent sample period. 


\section{Data}

We use monthly data for nine industrialized countries: Australia, Canada, France, Germany, Japan, the Netherlands, Switzerland, United Kingdom, and the United States. Nominal exchange rates for all countries are taken from the international Financial Statistics (IFS) tape (line ae). We analyze the period 1980:02-1999:06. The market weighted local equity indices and the market weighted global equity index are from Morgan Stanley Capital International (MSCI).

Data on individual stocks in this study is obtained from Datastream. We have downloaded stock prices, dividend yields, and dividends of firms that are included in the Datastream equity lists. If dividends are unavailable, the dividend yield is used. If neither dividend data nor dividend yields are available, the stock is excluded from the sample. We also exclude stocks that have not been continuously listed over the whole period. Furthermore, the data is filtered for data errors; stocks with outlier observations are excluded from the sample 4

Table 1 presents summary statistics for local and global stock market (MSCI) returns, and exchange rate returns. Returns are measured as logarithmic differences and given in percentages per month. The average domestic market return in local currency ranges from 0.63 for Japan to 1.51 for the Netherlands. Corresponding standard deviations vary between 6.20 for Australia and 4.32 for the U.S.. Columns seven and eight contain summary statistics of the MSCI world market portfolio expressed in local currency. Again, Japan is an outlier with an exceptionally low average return related to a substantial appreciation of the Yen.

Correlations between local and global stock market returns in U.S. dollars are provided in panel A of table 2. Domestic stock markets generally move together, though far from perfectly. Correlations range from 0.31 (Australia and Canada versus Japan) to 0.73 (Canada versus the U.S). The Japanese stock market appears to have relatively low correlations with the rest of the world. Panel B of table 2 shows correlations between U.S. dollar exchange rate changes. They range from 0.10 for the Canadian versus the Japanese exchange rate to 0.99 for the bilateral rates for Germany and the Netherlands. The European currencies appear to move roughly up and down together. Japan, Australia, and Canada have more idiosyncratic dollar exchange rate movements, with low correlation both among

\footnotetext{
4 These are stocks with average annual returns larger than $200 \%$, stocks with a local beta smaller than 0.1 , and infrequently traded stocks which have a zero return for more than twenty percent of the observations.
} 
themselves and relative to the European countries. In panel $\mathrm{C}$ of table 2, correlation coefficients between local and global stock market returns expressed in U.S. dollars versus bilateral nominal exchange rate changes against the U.S. dollar are reported for each pair of countries. Correlations between stock returns and exchange rate changes are generally relatively low, with the exception of the correlations between the domestic stock market return of a country and the return of its currency against the U.S. dollar.

One could argue that the pricing error between the domestic CAPM and the single factor ICAPM (without currency risk factors) will tend to be small, as the domestic market portfolios are relatively highly correlated with the global market portfolio 5 When currency risk factors are omitted from the analysis, the difference between the "direct" and the "indirect" approach of computing the cost of capital may be small for companies from countries which local stock market is highly correlated with the global market. In our analysis, however, we explicitly incorporate exchange rate risk factors into the ICAPM. As is mentioned in section 2, several recent studies, e.g. Dumas and Solnik (1995) and De Santis and Gérard (1998), present evidence that currency risk is priced for firms from a variety of countries. We argue that in the presence of multiple risk factors exposure to local market risk cannot generally be expected to capture the (multidimensional) exposure to the global factors. Therefore, we expect to find a substantial pricing error for the cross-listed firms in our sample, as these are probably highly exposed to international risk factors. The low correlations between the local market portfolios and the eight bilateral exchange rates reported in table 2 corroborate this argument.

Table 3 reports the number of stocks included for each country after the selection procedures. The total sample consists of 3,293 stocks with a complete series of returns for the period 1980:02-1999:06. The first and second columns of table 3 show the number of crosslisted companies, respectively the number of purely domestic stocks for each country. Our sample consists of more than 300 companies with cross-listings and almost 3,000 domestic firms. The other four columns of table 3 show the number of interlisted and domestic stocks for two subperiods, 1980:02-1989:12 and 1990:01-1999:06. The number of interlisted stocks is roughly the same for all sample periods. This is probably related to the fact that while the number of cross-border listings has increased sharply in the last decade, the study of Pagano, Röell, and Zechner (2002) suggests that the rise in cross-listings was less marked in the late

\footnotetext{
5 This supposition is, however, questioned by the analysis of Stulz (1995), who finds a considerable pricing error between the domestic CAPM and the single factor ICAPM of Grauer, Litzenberger, and Stehle (1976) for the Swiss multinational Nestlé.
} 
1980s and early 1990s. The total amount of domestic stocks varies widely, however. Our main empirical analysis focuses on cross-listed stocks. We use our sample of domestic stocks as a benchmark in order to assess to what extent the pricing error of cross-listed stocks diverges from those of domestic companies.

\section{Empirical Results}

In this section we discuss our empirical analysis of companies with international listings as well as domestic firms. Section 4.1 examines the pricing error results. In section 4.2 we present a variance decomposition analysis that explores the contribution of both local and global factors to the returns of cross-listed stocks. This decomposition provides a plausible rationale for our pricing error test results. Finally, as a related issue we examine the exchange rate exposure of interlisted firms in section 4.3.

\subsection{Pricing Error}

As previous studies indicate that firms with international listings are predominantly internationally oriented, our hypothesis is that these corporations have a considerable pricing error. The first column of table 4 presents rejection percentages of the Pricing Error test for interlisted companies. This test examines whether the firm's cost of capital is different when estimated with the domestic CAPM instead of the multifactor ICAPM. We find a significant pricing error for approximately 12 percent of the 336 firms. It is interesting to note that companies with a significant pricing error are typically from the large countries in our sample, such as Germany, Japan, the U.K., and the U.S.

The fourth column of table 4 contains rejection frequencies of the Global Beta test. This test evaluates the significance of the first element of the pricing error, also referred to as the beta error. The beta error is computed as the difference between the "direct beta" (the multifactor ICAPM beta $d_{i 1}$ ) and the "indirect beta" (the global beta of the local market $d_{L 1}$ multiplied by the CAPM beta $b_{i}$ ) of a firm. The beta error is significantly different from zero for 7.44 percent of the cross-listed firms.

In addition, table 4 shows rejection frequencies of the Pricing Error test and the Global Beta test for two subperiods. For the period 1980:02-1989:12, the Pricing Error test rejects for 4.19 percent of the 336 firms in the sample and the rejection frequency of Global Beta test is equal to 11.98 percent. The hypothesis of no pricing error is rejected for 26 out of 334 
interlisted companies in the subperiod 1990:01-1999:06. The Global Beta test rejects for 7.49 percent of the firms. The fact that the hypothesis that the pricing error is equal to zero is rejected for a similar number of firms over the two subsamples suggests that the assumption that betas are not time-varying does only have a marginal impact on our results.

Table 5 shows the average, the average of the absolute value, the standard deviation, the minimum, and the maximum of the beta error for our sample of cross-listed stocks. The average beta error is depicted in the first column of table 5 and is relatively close to zero. 6 The second column shows that the absolute beta error amounts to around 0.1 for most countries, varying from 0.056 for the Germany to 0.142 for Canada. The average of the absolute beta errors of all interlisted firms in the U.S. is equal to 0.067 . The (discrete) annual return on the global market portfolio over the sample period was 15.2 percent when expressed in U.S. dollars. The one-month risk free rate amounted to 7.8 percent on average. Consequently, the global market risk premium in U.S. dollars was equal to approximately 7.4 percent. The implied cost of capital differential between the CAPM and the ICAPM is then 50 basis points on average for U.S. firms. Th cost of capital terms the beta error amounts to 53 basis points for Germany, 90 basis points for Japan, 80 basis points for the U.K., and 112 basis points for Canada. Averaged over all countries, the implied cost of capital difference is approximately 80 basis points for interlisted stocks.

Table 6 depicts the results of both pricing error tests for our benchmark sample of domestic stocks. On average, the Pricing Error test rejects for 4.40 percent of the firms. This number varies only slightly across countries. Column 4 of table 6 shows the rejection percentages per country of the Global Beta test. This test detects a significant beta error for 2.44 percent of the domestic corporations. Table 6 also presents test results for subperiods, which are remarkably similar to the results for the whole sample period. Summary statistics of the first element of the pricing error for domestic firms are presented in table 7 . The average beta error is depicted in the first column and is close to zero, as expected. The second column

6 The value-weighted sum of the ICAPM betas equals unity. Also, each local market is priced correctly by the ICAPM, according to the internationally undiversifiable risks of that portfolio. By construction the market weighted average pricing error is equal to zero. This means that for an individual firm the CAPM and the ICAPM might give different cost of capital but on average, (value-weighted) domestic pricing provides the correct cost of capital. Note that the above characteristics only hold in a world where both local and global market indexes are measured perfectly including all individual stocks. Non-zero average pricing errors arise first because we do not use all stocks included in the local and global MSCI indices, and second because we present equally weighted averages.

7 In the absence of currency risk premia (and in the absence of deviations from the restriction $\alpha_{1 i}=\alpha_{2 i}+b_{i} \alpha_{L}$ ) the difference $\left(d_{L} b_{i}-d_{i}\right) E\left[R_{G}-r_{0}\right]$ would give an estimate of the cost of capital difference between the domestic and the international CAPM. 
shows that the absolute beta error is approximately 0.1 for most countries, varying from 0.077 for the U.S. to 0.123 for France. The implied cost of capital differential is equal to 57 basis points for the U.S., 75 basis points for Germany and Japan, 70 basis points for the U.K., and 106 basis points for Switzerland. On average, the estimated cost of capital differential for domestic stocks is very similar to the differential for interlisted stocks. Hence, the evidence indicates that the pricing error is very infrequently significantly different from zero for domestic firms as well.

Overall, our pricing error results provide little evidence for our hypothesis that the pricing error is economically and statistically large for cross-listed firms. The percentage of firms with a significant pricing error is only slightly larger for cross-listed companies than for domestic firms. Section 4.2 attempts to explore these results by decomposing the variance of a cross-listed stock into local and global factors. The aim of this analysis is to assess the marginal contribution of the global market index and the currency factors to the explanatory power of the domestic stock market portfolio.

\subsection{Variance Decomposition}

In this section we investigate how much of the risk that is specific in the local market is systematic in the global capital market. We assess the respective contributions of the local market, the global market and the vector of exchange rate changes to an individual asset $i$ 's return in a variance decomposition analysis. This analysis may shed light on our finding that the domestic CAPM leads to a different estimate of a firm's cost of capital than the multifactor ICAPM for a small percentage of the firms with foreign listings in our sample.

The decomposition assesses how much the global market index and the currency risk factors add to the local market index as a measure of systematic risk in the CAPM. We consider the regression

$$
R_{i}=\alpha_{5 i}+R_{L} b_{i}+\eta_{Z}{ }^{\prime} h_{i}+\xi_{i},
$$

where $\eta_{Z}$ represents the residual vector from regressing $Z$ on $R_{L}$. In equation (10) we can estimate the marginal contribution of the global factors to the explanatory power of the regression conditional on the contribution of the local market. Under the null hypothesis that the pricing error is equal to zero, the global risk factors are fully accounted for by the local market index. Equation (10) is a simple reparametrization of equation (8), but directly yields the additional explanatory power of the global factors $Z$. Taking the variance of both the left and the right hand side of equation (10), the variance of stock $i$ can be decomposed as 


$$
\omega_{i}^{2}=b_{i}^{2} \omega_{L}^{2}+h_{i}^{\prime}\left(\Omega+\frac{\Omega d_{L} d_{L}^{\prime} \Omega}{\omega_{L}^{2}}\right) h_{i}+\sigma_{i}^{2}
$$

In equation (11) the total variance of stock $i$ (denoted by $\omega_{i}{ }^{2}$ ) is decomposed into systematic local market risk (related to the variance $\omega_{L}^{2}$ of the local market return), additional global risk in $Z$ that is orthogonal to the local market (related to the covariance matrix $\Omega$ of $Z$ ) and specific risk $\sigma_{i}{ }^{2}$. Note that the contribution of the global factors should be zero under the null hypothesis that the cost of capital differential is equal to zero. That is, the estimate of $h_{i}$ must equal zero under the null hypothesis.

Figure 2 presents the average variance decomposition of all cross-listed firms per country. The variance decomposition for a country is a weighted average of the decompositions for all individual firms in that country with the specific risk of these firms as weights. Obviously, the marginal contribution of the global factors $Z$ across firms in one country is very small on average. While the exchange rate risk factors exhibit some explanatory power, the contribution of the global market index is trivial. Figure 2 thus confirms our finding that the domestic CAPM and the multifactor ICAPM yield a different estimate of the cost of capital for a relatively small percentage of firms. The variance decomposition analysis indicates significant country effects in interlisted stock returns, consistent with the evidence of Heston and Rouwenhorst (1994) and Griffin and Karolyi (1998).

Figure 2 suggests that interlisted firms within one country share a common exposure to the global market and currency factors. The exposure to global factors appears to be captured in the international pricing of the local market index, indicating that the local market is a sufficient statistic for measuring a firm's sensitivity to global factors. This means that even in integrated markets the pricing error is very small for most firms, because the local market factor can serve as a proxy for the omitted global factors in the domestic CAPM. A significant pricing error arises only for firms that have significantly deviating exposure from the average firm in their country. Our evidence indicates that the sensitivity of stocks with international listings to global factors does not substantially deviate from the exposure of the average firm in the market index of their home country.

The results in sections 4.1 and 4.2 indicate that a firm's risk profile is closely linked to its home country. This holds for the large majority of the cross-listed firms in our sample. A tentative explanation of this finding is related to what De Ménil (1999) calls lack of real capital market integration. De Ménil (1999) finds that both cyclical, structural, and institutional country-specific factors significantly contribute to the explanation of cross- 
country differences in ROA for large non-financial firms. More in particular, he finds significant effects for the level of capital deepening and for the regulatory environment. With respect to the latter, De Ménil points to labor and product market regulation as significant determinants of firm performance. In this respect, all firms within the same country face similar constraints and opportunities. In short, with a lack of real capital market integration and substantial cross-country differences in market regulation, a country's fortunes and the fortunes of the firms operating in this country are closely tied together. It may be true that certain firm characteristics such as size and degree of international activities play a role in explaining the deviating exposure of a firm relative to the local market. Further research is required to examine this issue.

Increasing harmonization of regulatory policies as is happening in the EU will reduce these structural differences. In the same vein, increasing real integration will reduce cyclical differences. For the time being, substantial differences remain between countries and firms across countries. These differences could be used by individual investors for the purpose of portfolio diversification. Note that the lack of real integration is separate from the issue of financial integration. Because we take the ICAPM as the null-hypothesis, we implicitly assume that stock markets are fully integrated. Consequently, our results have no implications for the financial integration of international capital markets.

In section 4.3 we present another way to illustrate the importance of country factors in the returns of interlisted stocks. We show that the pricing error tests in this paper are very similar to the well-known tests for foreign exchange rate exposure. We employ various exposure tests for our sample of interlisted firms. Our analysis indicates that currency exposure test are similarly affected by country factors as our tests for pricing errors.

\subsection{Country Factors and Exchange Rate Exposure}

In this section we analyze foreign exchange rate exposure for cross-listed companies. Adler and Dumas (1984) define exchange rate exposure as the impact of exchange rate movements on the value of a firm. We test for currency exposure of individual companies in the timeseries regression

$$
R_{i}=\gamma_{0 i}+R_{L} \gamma_{1 i}+S^{\prime} \gamma_{2 i}+\varepsilon_{i}
$$

\footnotetext{
8 Recent papers in the literature, e.g. Jorion (1990), Bartov and Bodnar (1994), and He and Ng (1998), base their tests on an analogous regression, but use a trade-weighted exchange rate index.
} 
The null-hypothesis of the test for currency exposure can be formulated as $\mathrm{H}_{0}: \gamma_{2 i}=0$. This test is called the "Exposure" test. It uses a subset of the orthogonality conditions in equation (8). As shown in section 2, testing for a pricing error boils to examining whether a set of instrumental variables is orthogonal to the residuals from the domestic CAPM regression (4). The Exposure test can also be interpreted as a pricing error test as it analyzes whether any systematic currency risk can be filtered out from the risk of a firm that is diversifiable domestically.

As suggested in section 4.2, foreign currency exposure as estimated in equation (12) may (in part) be captured by the domestic market factor, as most firms within a country exhibit a common exposure to global factors. In order to control for this country factor effect we also run the alternative regression

$$
R_{i}=c_{0 i}+S^{\prime} c_{1 i}+\eta_{G} c_{2 i}+\eta_{L} c_{3 i}+v_{i},
$$

where $\eta_{G}$ is the residual vector from regressing $R_{G}$ on an intercept and $S$. Similarly, $\eta_{L}$ is the residual vector from regressing $R_{L}$ on an intercept, $R_{G}$ and $S$. By orthogonalizing $R_{L}$, we want to accomplish that the coefficient on $S$ does not merely reflect the deviating exposure of firm $i$ from the average currency exposure of all firms in the country. The test of $c_{l i}=0$ is called the "Total Exposure" test.

A third alternative test for exchange rate exposure we consider is based on the regression

$$
R_{i}=\alpha_{1 i}+R_{G} d_{i 1}+S^{\prime} d_{i 2}+u_{i}
$$

Note that equation (14) is the same as equation (2). The test of $H_{0}: d_{i 2}=0$ looks for significant "Currency Betas".

Several recent studies in the literature, e.g. Jorion (1990), Bartov and Bodnar (1994), and $\mathrm{He}$ and $\mathrm{Ng}$ (1998), hardly find any evidence of significant foreign exchange rate exposure in a variety of samples. Bartov and Bodnar argue that these results may be partly due to sample selection criteria. We expect to find considerable exposure to exchange rates in our sample of cross-listed companies, as a high percentage of their sales are realized abroad.

Table 8 shows the percentage of interlisted firms with significant exposure to foreign exchange rates. Column 1 depicts the rejection percentages of the Exposure test, which is very similar to the tests used in the recent literature. This test is rejected for 25 percent of the crosslisted companies. This result is comparable to e.g. $\mathrm{He}$ and $\mathrm{Ng}$ (1998), who find significant exposure for 25 percent in a sample of Japanese firms. The rejection percentages of the Total Exposure test as depicted in column 2 of table 8 are importantly higher than those of the 
Exposure test. Almost 82 percent of the cross-listed stocks exhibit significant exposure. Similar figures are obtained with the Currency Betas test. This implies that the results from the Exposure test are strongly affected by the country factors in the data. When we control for this effect, we find strong evidence for our hypothesis that the value of stocks with overseas listings is highly sensitive to fluctuations in exchange rates. It could be argued that the stock prices of cross-listed companies can be expected to be relatively responsive to exchange rate shocks, as the absence of arbitrage opportunities implies that stock prices in the home and foreign are equal when expressed in a common currency. We contend, however, that this type of currency adjustments plays a role at a much higher frequency than we consider. Moreover, the evidence of Grammig, Melvin, and Schlag (2000) suggests that the high-frequency adjustment to exchange rate shocks may well be born by the price in the derivative market, while we only study stock returns in the home market.

\section{Conclusions}

As companies become more and more internationally oriented, international listings are an increasingly important part of a firm's long-term strategic policy. Two main issues can be distinguished in the literature on stocks with overseas listings. The first strand of the literature focuses on the question whether the stock market performance, the liquidity, and the cost of capital of a company change as a consequence of listing abroad. The second strand examines the motivations and features of companies that obtain an overseas listing.

We focus on the question whether international and domestic asset pricing models lead to different estimates of the cost of capital for interlisted companies. We examine the socalled pricing error, which is linearly related to the computed cost of capital differential, for a sample of monthly data for 336 cross-listed firms from nine major industrialized countries from 1980 to 1999. We distinguish between: (i) the multifactor ICAPM of Solnik-Sercu including both the global market portfolio and exchange rate risk premia, and (ii) the single factor domestic CAPM.

Our hypothesis is that the pricing error is considerable for interlisted firms, as they are relatively internationally oriented. We find a significant cost of capital differential for only 12 percent of the cross-listed corporations, however. The cost of capital differential between the

9 Estimation results for subperiods are qualitatively similar. They are not reported in this paper but are available from the authors on request. 
domestic CAPM and the ICAPM amounts to 50 basis points for the U.S., 75 basis points for the U.K., and 100 basis points for France. Our analysis thus provides little evidence in favor of our hypothesis that companies with an overseas listing exhibit a relatively large pricing error. Using a variance decomposition analysis we demonstrate that this results are probably due to strong country factors in the data. Firms within a country generally exhibit a similar exposure to international currency and stock market factors. Since such average exposure is captured in the international pricing of the local stock market index, the CAPM induces a pricing error only for firms that have significantly deviating exposure. Most companies can therefore rely on the domestic CAPM for the computation of their cost of capital.

A tentative explanation for the strong country-specific factors in individual stock returns is a lack of real capital market integration, due to both cyclical, structural, and institutional country-specific factors. As asset returns contain large country-specific components, investing in different industries within one country is insufficient to reap all the benefits of portfolio diversification in a global setting. In that sense, our evidence reinforces the home bias puzzle. Further research is required to examine these issues. 


\section{Appendix A}

In this appendix we show that the pricing error of the CAPM as compared to the multifactor ICAPM of Solnik-Sercu can be expressed as a linear combination of the parameter $\delta_{i}$ in the regression (8) in the text

$$
R_{i}=\alpha_{4 i}+R_{L} \beta_{i}+Z^{\prime} \delta_{i}+\zeta_{i} .
$$

This is equation (8) in the paper. The moment conditions of equation (A1) can be written as

$$
\left(\begin{array}{cc}
\omega_{L}^{2} & d_{L}^{\prime} \Omega \\
\Omega d_{L} & \Omega
\end{array}\right)\left(\begin{array}{l}
\beta_{i} \\
\delta_{i}
\end{array}\right)=\left(\begin{array}{c}
\omega_{L}^{2} b_{i} \\
\Omega d_{i}
\end{array}\right),
$$

where $\Omega$ is the $(N+1) \times(N+1)$ covariance matrix of $Z, \omega_{L}^{2}$ is the variance of $R_{L}$, and $d_{L}$ is the vector of regression parameters in regression (5) in the text

$$
R_{L}=\alpha_{L}+Z^{\prime} d_{L}+u_{L}
$$

for the local market portfolio. The covariance between $Z$ and $R_{L}$ is therefore equal to $\Omega d_{L}$. Solving for $\delta_{i}$ from the second line of (A2) we get

$$
\delta_{i}=d_{i}-d_{L} \beta_{i}
$$

Substituting this expression into the first line of equation (A2) gives

$$
\beta_{i}=\frac{\omega_{L}^{2} b_{i}-d_{L}^{\prime} \Omega d_{i}}{\omega_{L}^{2}-d_{L}^{\prime} \Omega d_{L}}=b_{i}-\frac{d_{L}^{\prime} \Omega p_{i}}{\sigma_{L}^{2}},
$$

where $p_{i}=d_{L} b_{i}-d_{i}$ is the pricing error and $\sigma_{L}^{2}$ is the variance of residuals $u_{L}$. Substituting this expression for $\beta_{i}$ back into equation (A4) yields

$$
\delta_{i}=\left(\mathrm{I}+\frac{d_{L} d_{L}^{\prime} \Omega}{\sigma_{L}^{2}}\right) p_{i} .
$$

Equation (A6) can be rewritten as

$$
p_{i}=\left(\mathrm{I}+\frac{d_{L} d_{L}^{\prime} \Omega}{\sigma_{L}^{2}}\right)^{-1} \delta_{i} .
$$

Note that $d_{L}, \Omega$, and $\sigma_{L}^{2}$ are unrelated to asset $i$ and are treated as exogenous. 


\section{References}

Adler, M., and B. Dumas, 1983, "International Portfolio Choice and Corporation Finance: A Synthesis," Journal of Finance, 38, 925-984.

Adler, M., and B. Dumas, 1984, "Exposure to Currency Risk: Definition and Measurement," Financial Management, 13, 41-50.

Bartov, E., and G.M. Bodnar, 1994, "Firm Valuation, Earnings Expectations, and the Exchange Rate Exposure Effect," Journal of Finance, 49, 1755-1785.

Bekaert, G., and C.R. Harvey, 1995, “Time-Varying World Market Integration,” Journal of Finance, 50, 403-444.

Biddle, G., and S. Saudagaran, 1989, "The Effects of Financial Disclosure Levels on Firms' Choices among Alternative Foreign Stock Exchanges," Journal of International Financial Management and Accounting, 1, 55-87.

Campbell, J.Y., and Y. Hamao, 1992, "Predictable Stock Returns in the United States and Japan: A Study of Long-Term Capital Market Integration,” Journal of Finance, 47, $43-69$.

De Ménil, G., 1999, "Real Capital Market Integration in the EU: How Far Has it Gone? What Will the Effect of the Euro Be? (with discussion)," Economic Policy, 28, 167-204.

De Santis, G., and B. Gérard, 1997, "International Asset pricing and Portfolio Diversification with Time-Varying Risk," Journal of Finance, 52, 1881-1912.

De Santis, G., and B. Gérard, 1998, "How Big is the Premium for Currency Risk?," Journal of Financial Economics, 49, 375-412.

Doukas, J., and L.N. Switzer, 2000, "Common Stock Returns and International Listing Announcements: Conditional Tests of the Mild Segmentation Hypothesis," Journal of Banking and Finance, 24, 471-502.

Dumas, B., and B. Solnik, 1995, "The World Price of Exchange Rate Risk," Journal of Finance, 50, 445-479.

Eun, C.S., and S. Sabherwal, 2002, "Cross-Border Listings and Price Discovery: Evidence from U.S. Listed Canadian Stocks," Journal of Finance, forthcoming.

Foerster, S.R., and G.A. Karolyi, 1993, "International Listings of Stocks: The Case of Canada and the U.S.," Journal of International Business Studies, 24, 763-784. 
Foerster, S.R., and G.A. Karolyi, 1998, "The Effects of Market Segmentation and Investor Recognition on Asset Prices: Evidence from Foreign Stock Listings in the U.S.," working paper, Ohio State University.

Fuerst, O., 1998, “A Theoretical Analysis of the Investor Protection Regulations Argument for Global Listing of Stocks,” working paper, Yale University.

Grammig, J., M. Melvin, and C. Schlag, 2000, "Price Discovery in International Equity Trading," working paper, Arizona State University.

Grauer, F.L.A., R.H. Litzenberger, and R.E. Stehle, 1976, "Sharing Rules and Equilibrium in an International Capital Market Under Uncertainty," Journal of Financial Economics, $3,233-256$.

Griffin, J.M., and G.A. Karolyi, 1998, “Another Look at the Role of the Industrial Structure of Markets for International Diversification Strategies," Journal of Financial Economics, $50,351-373$.

Gultekin, M.N., Gultekin, N.B., and A. Penati, 1989, "Capital Controls and International Capital Market Segmentation: The Evidence from the Japanese and American Stock Markets," Journal of Finance, 44, 849-869.

Harvey, C.R., 1991, “The World Price of Covariance Risk," Journal of Finance, 46, 111-157.

He, J., and L.K. Ng, 1998, “The Foreign Exchange Exposure of Japanese Multinational Corporations," Journal of Finance, 53, 733-753.

Heston, S.L., and K.G. Rouwenhorst, 1994, "Does Industrial Structure explain the Benefits of International Diversification?," Journal of Financial Economics, 36, 3-27.

Jorion, P., 1990, “The Exchange Rate Exposure of U.S. Multinationals,” Journal of Business, $63,331-345$.

Jorion, P., and E. Schwartz, 1986, "Integration vs. Segmentation in the Canadian Stock Market," Journal of Finance 41, 603-616.

Karolyi, G.A., 1998, "Why Do Companies List Shares Abroad?: A Survey of the Evidence and Its Managerial Implications," Financial Markets, Institutions \& Instruments, 7 , Number 1.

Koedijk, C.G., C.J.M. Kool, P.C. Schotman, and M. A. van Dijk, 2001, “The Cost of Capital in International Financial Markets: Local or Global?," CEPR Discussion Paper, 3062, forthcoming (2002) Journal of International Money and Finance.

Pagano, M., A.A. Röell, and J. Zechner, 2002, “The Geography of Equity Listing: Why Do Companies List Abroad?," Journal of Finance, forthcoming. 
Saudagaran, S., 1988, "An Empirical Study of Selected Factors Influencing the Decision to List on Foreign Stock Exchanges," Journal of International Business Studies, 19, $101-127$.

Sercu, P., 1980, “A Generalization of the International Asset Pricing Model," Revue de l'Association Française de Finance, 1, 91-135.

Sercu, P., and R. Uppal, 1995, International Financial Markets and the Firm, South-Western College Publishing, Cincinnatti, Ohio.

Solnik, B., 1974, “An Equilibrium Model of the International Capital Market," Journal of Economic Theory, 8, 500-524.

Stulz, R.M., 1995, "The Cost of Capital in Internationally Integrated Markets: The Case of Nestlé," European Financial Management, 1, 11-22.

Vassalou, M., 2000, “Exchange Rate and Foreign Inflation Risk Premiums in Global Equity Returns," Journal of International Money and Finance, 19, 433-470.

Werner, L., and A. Kleidon, 1996, "U.S. and U.K. Trading of British Cross-Listed Stocks: An Intraday Analysis of Market Integration," Review of Financial Studies, 9, 619-664. 
Table 1

\section{Summary Statistics (returns in \% per month)}

This table presents summary statistics for the local market index in local currency and in U.S. dollars, the nominal exchange rate and the global market index denoted in local currency for each of the nine countries in our sample. The first two columns contain the mean return and standard deviation of the MSCI country indices expressed in local currency. The third and the fourth column present the mean and standard deviation of exchange rate returns against the U.S. dollar. Columns five and six reflect the mean return and standard deviation of the MSCI country indices expressed in U.S. dollar. Finally, the last two columns depict the mean return and standard deviation of the MSCI world index expressed in local currency. The sample period is 1980:02-1999:06. Data on domestic and global market indices is obtained from MSCI. Nominal exchange rates are taken from the International Financial Statistics (IFS) tape.

\begin{tabular}{lcccccccc}
\hline & \multicolumn{2}{c}{$\begin{array}{c}\text { Local MSCI } \\
\text { (in local currency) }\end{array}$} & \multicolumn{2}{c}{$\begin{array}{c}\text { FX-return } \\
\text { (against US\$) }\end{array}$} & \multicolumn{2}{c}{$\begin{array}{c}\text { Local MSCI } \\
\text { (in US\$) }\end{array}$} & \multicolumn{2}{c}{$\begin{array}{c}\text { Global MSCI } \\
\text { (in local currency) }\end{array}$} \\
\cline { 2 - 9 } Country & Mean & StDv & Mean & StDv & Mean & StDv & Mean & StDv \\
\hline Australia & 1.04 & 6.20 & -0.22 & 2.88 & 0.82 & 7.53 & 1.40 & 4.60 \\
Canada & 0.81 & 4.96 & -0.10 & 1.32 & 0.71 & 5.60 & 1.28 & 3.94 \\
France & 1.30 & 5.96 & -0.19 & 3.29 & 1.11 & 6.43 & 1.37 & 4.77 \\
Germany & 1.11 & 5.74 & -0.04 & 3.32 & 1.07 & 6.14 & 1.21 & 4.76 \\
Japan & 0.63 & 5.74 & 0.29 & 3.52 & 0.92 & 6.96 & 0.89 & 4.55 \\
Netherlands & 1.51 & 5.09 & -0.05 & 3.32 & 1.46 & 5.10 & 1.22 & 4.74 \\
Switzerland & 1.14 & 5.06 & 0.02 & 3.65 & 1.16 & 5.51 & 1.16 & 5.04 \\
United Kingdom & 1.40 & 4.99 & -0.16 & 3.28 & 1.24 & 5.68 & 1.33 & 4.54 \\
United States & 1.36 & 4.32 & - & - & 1.36 & 4.32 & 1.18 & 4.17 \\
\hline
\end{tabular}


Table 2

\section{Correlation Matrices}

Panel A of this table presents correlation coefficients of the returns on the local and global market indices expressed in U.S. dollars. Panel B contains correlation coefficients of the exchange rate changes against the U.S. dollar. Panel $\mathrm{C}$ shows correlation coefficients between the local and global market returns expressed in U.S. dollars and the exchange rate changes against the U.S. dollar. The sample period is 1980:02-1999:06. Data on domestic and global market indices is obtained from MSCI. Nominal exchange rates are taken from the International Financial Statistics (IFS) tape.

\begin{tabular}{|c|c|c|c|c|c|c|c|c|c|}
\hline & Aus & Can & Fra & Ger & Jap & Net & Swi & Ukd & Usa \\
\hline \multicolumn{10}{|c|}{ Panel A: Stock market returns (in US\$) } \\
\hline Global MSCI & 0.56 & 0.72 & 0.65 & 0.61 & 0.73 & 0.76 & 0.69 & 0.75 & 0.80 \\
\hline Australia & 1 & 0.61 & 0.37 & 0.36 & 0.31 & 0.45 & 0.42 & 0.56 & 0.49 \\
\hline Canada & & 1 & 0.43 & 0.42 & 0.31 & 0.61 & 0.50 & 0.59 & 0.73 \\
\hline France & & & 1 & 0.68 & 0.39 & 0.64 & 0.62 & 0.56 & 0.48 \\
\hline Germany & & & & 1 & 0.33 & 0.70 & 0.71 & 0.51 & 0.44 \\
\hline Japan & & & & & 1 & 0.41 & 0.41 & 0.42 & 0.27 \\
\hline Netherlands & & & & & & 1 & 0.71 & 0.72 & 0.62 \\
\hline Switzerland & & & & & & & 1 & 0.59 & 0.53 \\
\hline United Kingdom & & & & & & & & 1 & 0.58 \\
\hline United States & & & & & & & & & 1 \\
\hline \multicolumn{10}{|c|}{ Panel B: Exchange rate returns (against US\$) } \\
\hline Australia & 1 & 0.31 & 0.17 & 0.11 & 0.18 & 0.12 & 0.11 & 0.23 & - \\
\hline Canada & & 1 & 0.15 & 0.15 & 0.10 & 0.16 & 0.12 & 0.23 & - \\
\hline France & & & 1 & 0.96 & 0.57 & 0.96 & 0.89 & 0.70 & - \\
\hline Germany & & & & 1 & 0.59 & 0.99 & 0.93 & 0.70 & - \\
\hline Japan & & & & & 1 & 0.59 & 0.62 & 0.47 & - \\
\hline Netherlands & & & & & & 1 & 0.92 & 0.72 & - \\
\hline Switzerland & & & & & & & 1 & 0.66 & - \\
\hline United Kingdom & & & & & & & & 1 & - \\
\hline \multicolumn{10}{|c|}{ Panel C: Stock market returns (in US\$) versus exchange rate returns (against US\$) } \\
\hline Global MSCI & 0.19 & 0.32 & 0.20 & 0.21 & 0.31 & 0.21 & 0.17 & 0.27 & - \\
\hline Australia & 0.61 & 0.35 & 0.05 & 0.00 & 0.11 & 0.01 & 0.00 & 0.17 & - \\
\hline Canada & 0.26 & 0.58 & 0.04 & 0.02 & 0.07 & 0.04 & 0.00 & 0.13 & - \\
\hline France & 0.14 & 0.20 & 0.39 & 0.36 & 0.26 & 0.37 & 0.28 & 0.28 & - \\
\hline Germany & 0.11 & 0.19 & 0.36 & 0.39 & 0.19 & 0.38 & 0.29 & 0.27 & - \\
\hline Japan & 0.17 & 0.16 & 0.22 & 0.25 & 0.57 & 0.25 & 0.26 & 0.28 & - \\
\hline Netherlands & 0.14 & 0.28 & 0.30 & 0.33 & 0.23 & 0.33 & 0.27 & 0.29 & - \\
\hline Switzerland & 0.18 & 0.20 & 0.42 & 0.42 & 0.31 & 0.42 & 0.45 & 0.33 & - \\
\hline United Kingdom & 0.26 & 0.28 & 0.28 & 0.25 & 0.23 & 0.27 & 0.22 & 0.48 & - \\
\hline United States & 0.11 & 0.28 & -0.04 & -0.05 & -0.04 & -0.04 & -0.09 & -0.01 & - \\
\hline
\end{tabular}


Table 3

\section{Sample Composition}

This table presents the number of domestic and interlisted firms for different countries in three different sample periods. Columns one and two depict the number of companies in whole sample period 1980:02-1999:06. The third and the fourth columns show how many stocks the sample contains in the first subperiod 1980:02-1989:12. The number of corporations for the second subperiod 1990:011999:06 are reflected in the last two columns.

\begin{tabular}{|c|c|c|c|c|c|c|}
\hline \multirow[b]{2}{*}{ Country } & \multicolumn{2}{|c|}{$\begin{array}{c}\text { \# stocks } \\
\text { in whole sample } \\
\text { 1980:02-1999:06 }\end{array}$} & \multicolumn{2}{|c|}{$\begin{array}{c}\text { \# stocks } \\
\text { in } 1^{\text {st }} \text { subsample } \\
\text { 1980:02-1989:12 }\end{array}$} & \multicolumn{2}{|c|}{$\begin{array}{c}\text { \# stocks } \\
\text { in } 2^{\text {nd }} \text { subsample } \\
\text { 1990:01-1999:06 }\end{array}$} \\
\hline & Interlisted & Domestic & Interlisted & Domestic & Interlisted & Domestic \\
\hline Australia & 24 & 84 & 24 & 94 & 23 & 221 \\
\hline Canada & 29 & 190 & 29 & 202 & 29 & 316 \\
\hline France & 22 & 105 & 22 & 108 & 22 & 478 \\
\hline Germany & 24 & 154 & 24 & 157 & 24 & 408 \\
\hline Japan & 127 & 702 & 125 & 608 & 127 & 1,628 \\
\hline Netherlands & 26 & 97 & 26 & 100 & 26 & 134 \\
\hline Switzerland & 14 & 115 & 14 & 122 & 14 & 250 \\
\hline United Kingdom & 17 & 1,034 & 17 & 1,101 & 17 & 1,228 \\
\hline United States & 53 & 476 & 53 & 504 & 52 & 697 \\
\hline Total & 336 & 2,957 & 334 & 2,996 & 334 & 5,360 \\
\hline
\end{tabular}


Table 4

\section{Pricing Error Test Results for Interlisted Companies}

This table contains the rejection frequencies for of the pricing error tests for interlisted stocks. The Pricing Error test examines whether a pricing error exists between the domestic CAPM and the multifactor ICAPM. The Global Beta test is similar to the Pricing Error test but focuses on the beta error of the domestic CAPM versus the multifactor ICAPM. The asymptotic Wald tests are Chisquared distributed and robust to heteroskedasticity. Rejection frequencies are defined as the percentage of firms in a country for which the null-hypothesis is rejected at the 5 percent significance level. The row labeled "Average" depicts a weighted average of the percentages of firms in each individual country for which the null-hypothesis is rejected. The weights of the rejection frequencies are the weights of each country in the sample as shown in the first column of table 3 . The sample period is 1980:02-1999:06. Data on domestic and global market indices is obtained from MSCI. Data on individual stocks is obtained from the Datastream equity lists. Nominal exchange rates are taken from the International Financial Statistics (IFS) tape. Stocks with incomplete price or dividend data, stocks with outlier observation and illiquid stocks have been removed from the dataset. This table also shows the rejection frequencies for both tests for two subsamples. The first subsample consists of the period 1980:02-1989:12. The second subsample is the period 1990:01-1999:06.

\begin{tabular}{lcccccc}
\hline \multirow{2}{*}{ Country } & \multicolumn{3}{c}{$\begin{array}{c}\text { Pricing Error Test } \\
\text { percentage rejections }\end{array}$} & \multicolumn{3}{c}{$\begin{array}{c}\text { Global Beta Test } \\
\text { percentage rejections }\end{array}$} \\
\hline Australia & $1980-1999$ & $1980-1989$ & $1990-1999$ & $1980-1999$ & $1980-1989$ & $1990-1999$ \\
Canada & 4.17 & 4.17 & 4.35 & 4.17 & 8.33 & 17.39 \\
France & 6.90 & 3.45 & 3.45 & 6.90 & 13.79 & 6.90 \\
Germany & 4.55 & 0.00 & 4.55 & 0.00 & 13.64 & 0.00 \\
Japan & 12.50 & 4.17 & 4.17 & 4.17 & 4.17 & 4.17 \\
Netherlands & 19.69 & 4.80 & 11.02 & 14.17 & 20.80 & 9.45 \\
Switzerland & 3.85 & 0.00 & 0.00 & 3.85 & 0.00 & 0.00 \\
United Kingdom & 7.14 & 14.29 & 0.00 & 0.00 & 21.43 & 0.00 \\
United States & 5.88 & 0.00 & 11.76 & 0.00 & 0.00 & 0.00 \\
& 11.32 & 5.66 & 11.54 & 3.77 & 1.89 & 11.54 \\
Average & & & & & & \\
\hline
\end{tabular}


Table 5

\section{Summary Statistics of Difference Between Direct and Indirect Beta for Interlisted Companies}

This table shows summary statistics of the beta error for interlisted firms. The beta error is computed as the difference between the "direct beta" (the multifactor ICAPM beta $d_{i l}$ ) and the "indirect beta" (the global beta of the local market $d_{L l}$ multiplied by the CAPM beta $b_{i}$ ) of a firm. The columns present the mean, the mean of the absolute value, the standard deviation, the minimum and the maximum value of the beta errors, respectively. The sample period is 1980:02-1999:06. Data on domestic and global market indices is obtained from MSCI. Nominal exchange rates are taken from the International Financial Statistics (IFS) tape. Data on individual stocks is obtained from the Datastream equity lists. Stocks with incomplete price or dividend data, stocks with outlier observations and illiquid stocks have been removed from the dataset.

\begin{tabular}{lccccc}
\hline Country & Mean & Abs & StDv & Min & Max \\
\hline Australia & 0.009 & 0.094 & 0.128 & -0.209 & 0.306 \\
Canada & 0.005 & 0.142 & 0.179 & -0.449 & 0.355 \\
France & 0.063 & 0.118 & 0.124 & -0.187 & 0.278 \\
Germany & 0.026 & 0.056 & 0.071 & -0.081 & 0.202 \\
Japan & 0.032 & 0.137 & 0.171 & -0.330 & 0.469 \\
Netherlands & 0.055 & 0.081 & 0.080 & -0.118 & 0.226 \\
Switzerland & 0.100 & 0.103 & 0.088 & -0.013 & 0.280 \\
United Kingdom & 0.051 & 0.104 & 0.154 & -0.158 & 0.528 \\
United States & 0.024 & 0.067 & 0.084 & -0.185 & 0.251 \\
\hline
\end{tabular}


Table 6

\section{Pricing Error Test Results for Domestic Companies}

This table contains the rejection frequencies for of the pricing error tests for domestic stocks. The Pricing Error test examines whether a pricing error exists between the domestic CAPM and the multifactor ICAPM. The Global Beta test is similar to the Pricing Error test but focuses on the beta error of the domestic CAPM versus the multifactor ICAPM. The asymptotic Wald tests are Chisquared distributed and robust to heteroskedasticity. Rejection frequencies are defined as the percentage of firms in a country for which the null-hypothesis is rejected at the 5 percent significance level. The row labeled "Average" depicts a weighted average of the percentages of firms in each individual country for which the null-hypothesis is rejected. The weights of the rejection frequencies are the weights of each country in the sample as shown in the second column of table 3 . The sample period is 1980:02-1999:06. Data on domestic and global market indices is obtained from MSCI. Data on individual stocks is obtained from the Datastream equity lists. Nominal exchange rates are taken from the International Financial Statistics (IFS) tape. Stocks with incomplete price or dividend data, stocks with outlier observation and illiquid stocks have been removed from the dataset. The first subsample consists of the period 1980:02-1989:12. The second subsample is the period 1990:011999:06.

\begin{tabular}{lcccccc}
\hline Country & \multicolumn{3}{c}{$\begin{array}{c}\text { Pricing Error Test } \\
\text { percentage rejections }\end{array}$} & \multicolumn{3}{c}{$\begin{array}{c}\text { Global Beta Test } \\
\text { percentage rejections }\end{array}$} \\
\hline Australia & $1980-1999$ & $1980-1989$ & $1990-1999$ & $1980-1999$ & $1980-1989$ & $1990-1999$ \\
Canada & 3.76 & 3.19 & 2.72 & 1.19 & 3.19 & 8.15 \\
France & 3.68 & 3.47 & 3.80 & 6.84 & 5.94 & 8.54 \\
Germany & 6.67 & 1.85 & 2.09 & 5.71 & 4.63 & 9.41 \\
Japan & 5.84 & 3.82 & 2.45 & 1.95 & 4.46 & 2.94 \\
Netherlands & 3.28 & 2.47 & 3.32 & 2.14 & 7.40 & 7.06 \\
Switzerland & 8.25 & 1.00 & 2.24 & 5.16 & 6.00 & 7.46 \\
United Kingdom & 2.61 & 7.38 & 3.60 & 0.87 & 9.02 & 2.00 \\
United States & 4.16 & 4.18 & 2.85 & 1.45 & 4.00 & 4.89 \\
& 5.46 & 3.77 & 4.74 & 2.73 & 4.56 & 5.45 \\
Average & & & & & & \\
\hline
\end{tabular}


Table 7

\section{Summary Statistics of Difference Between Direct and Indirect Beta for Domestic Companies}

This table shows summary statistics of the beta error for domestic firms. The beta error is computed as the difference between the "direct beta" (the multifactor ICAPM beta $d_{i l}$ ) and the "indirect beta" (the global beta of the local market $d_{L I}$ multiplied by the CAPM beta $b_{i}$ ) of a firm. The columns present the mean, the mean of the absolute value, the standard deviation, the minimum and the maximum value of the beta errors, respectively. The sample period is 1980:02-1999:06. Data on domestic and global market indices is obtained from MSCI. Nominal exchange rates are taken from the International Financial Statistics (IFS) tape. Data on individual stocks is obtained from the Datastream equity lists. Stocks with incomplete price or dividend data, stocks with outlier observations and illiquid stocks have been removed from the dataset.

\begin{tabular}{lccccc}
\hline Country & Mean & Abs & StDv & Min & Max \\
\hline Australia & 0.010 & 0.122 & 0.169 & -0.487 & 0.693 \\
Canada & 0.042 & 0.118 & 0.151 & -0.616 & 0.489 \\
France & 0.033 & 0.123 & 0.153 & -0.384 & 0.497 \\
Germany & 0.012 & 0.079 & 0.103 & -0.306 & 0.310 \\
Japan & -0.027 & 0.114 & 0.150 & -0.853 & 0.495 \\
Netherlands & 0.058 & 0.101 & 0.118 & -0.276 & 0.441 \\
Switzerland & 0.077 & 0.104 & 0.112 & -0.158 & 0.426 \\
United Kingdom & 0.003 & 0.091 & 0.122 & -0.577 & 0.642 \\
United States & 0.039 & 0.077 & 0.107 & -0.457 & 0.478 \\
\hline
\end{tabular}


Table 8

\section{Foreign Exchange Rate Exposure Test Results for Interlisted Companies}

This table presents rejection frequencies for the exchange rate exposure tests for interlisted companies. The Exposure test examines foreign exchange rate exposure of individual stocks when controlled for the local market index. The Total Exposure test tests for exchange rate exposure when controlled for fluctuations in the local market index that are orthogonal to all exchange rates. The Currency Betas test tests for exposure of individual firms when the global market return is included in the regression. The asymptotic Wald tests are Chi-squared distributed and robust to heteroskedasticity. Rejection frequencies are defined as the percentage of firms in a country for which the null-hypothesis is rejected at the 5 percent significance level. The row labeled "Average" depicts a weighted average of the percentages of firms in each individual country for which the null-hypothesis is rejected. The weights of the rejection frequencies are the weights of each country in the sample as shown in the first column of table 3. The sample period is 1980:02-1999:06. Data on domestic and global market indices is obtained from MSCI. Data on individual stocks is obtained from the Datastream equity lists. Nominal exchange rates are taken from the International Financial Statistics (IFS) tape. Stocks with incomplete price or dividend data, stocks with outlier observation and illiquid stocks have been removed from the dataset.

\begin{tabular}{lccc}
\hline Country & $\begin{array}{c}\text { Exposure Test } \\
\text { percentage rejections }\end{array}$ & $\begin{array}{c}\text { Total Exposure Test } \\
\text { percentage rejections }\end{array}$ & $\begin{array}{c}\text { Currency Betas Test } \\
\text { percentage rejections }\end{array}$ \\
\hline Australia & 20.83 & 91.67 & 95.83 \\
Canada & 20.69 & 86.21 & 82.76 \\
France & 18.18 & 77.27 & 59.09 \\
Germany & 33.33 & 87.50 & 87.50 \\
Japan & 34.65 & 83.46 & 83.46 \\
Netherlands & 15.38 & 84.62 & 19.23 \\
Switzerland & 0.00 & 92.86 & 57.14 \\
United Kingdom & 5.88 & 82.35 & 58.82 \\
United States & 20.75 & 64.15 & 64.15 \\
& & & \\
Average & 24.70 & 81.55 & 72.62 \\
\hline
\end{tabular}


Figure 1

\section{Direct Versus Indirect Computation of the Cost of Capital}

This figure illustrates the fundamental issue examined in this paper. Under the maintained hypothesis that the multifactor ICAPM including currency risk premia holds, firms should compute the cost of capital by estimating the exposure of their stock to the global factors. In our empirical implementation, the global factors consist of the global market portfolio and eight exchange rate factors. We refer to this methodology as the "direct" way of determining a firm's cost of capital. Alternatively, a firm could use the single factor domestic CAPM for the calculation of the cost of capital. If the multifactor ICAPM applies to every individual stock, it also applies to the domestic market portfolio of every country. Consequently, using the CAPM can be regarded as an "indirect" way of computing the cost of capital in an international setting. The "indirect" approach will lead to the same cost of capital as the "direct" approach if a firm's (multidimensional) "indirect beta" is indistinguishable from its "direct beta".

\section{"indirect" cost of capital computation}

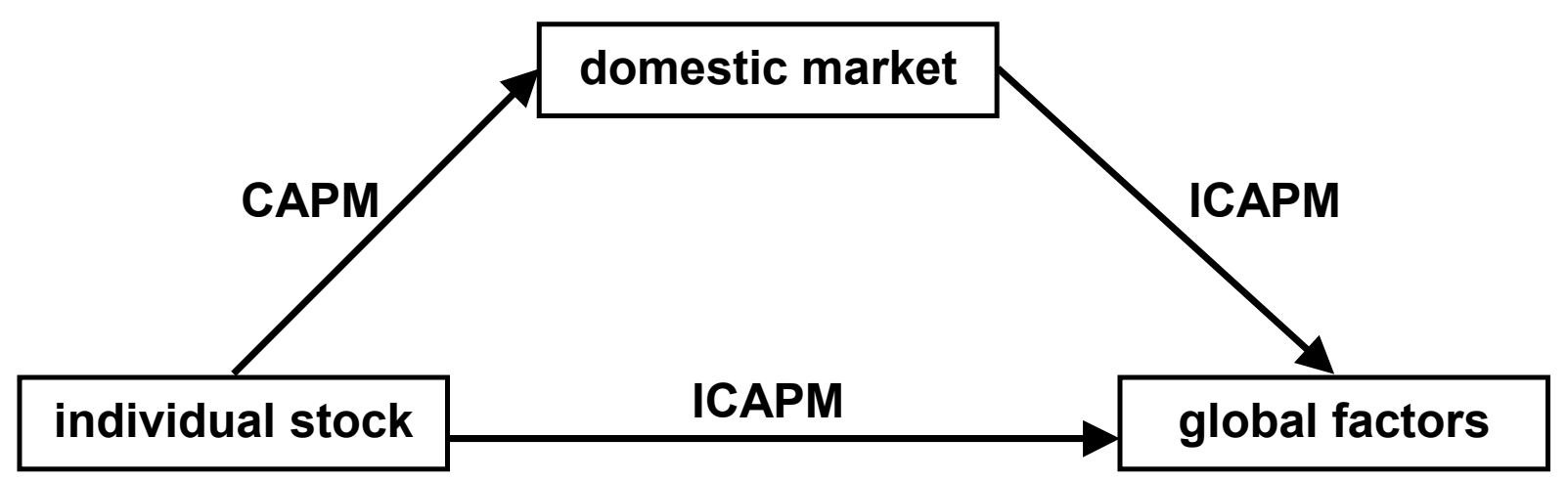

"direct" cost of capital computation 
Figure 2

\section{Average Pricing Error Decomposition for Interlisted Companies}

This figure presents a variance decomposition analysis for cross-listed companies. The general idea behind this decomposition is that the orthogonalized global market factor and the currency risk factors are added to the CAPM regression

$$
R_{i}=\alpha_{5 i}+R_{L} b_{i}+\eta_{Z}^{\prime} h_{i}+\xi_{i},
$$

where $\eta_{Z}$ is the residual vector from regressing $Z$ on $R_{L}$. This way the marginal contribution of the global factors conditional on the local contribution can be measured. Taking the variance of both the left and the right hand side of this equation, the variance decomposition of stock $i$ can be expressed as

$$
\omega_{i}^{2}=b_{i}^{2} \omega_{L}^{2}+h_{i}^{\prime}\left(\Omega+\frac{\Omega d_{L} d_{L}^{\prime} \Omega}{\omega_{L}^{2}}\right) h_{i}+\sigma_{i}^{2} .
$$

In this equation the total variance of stock $i$ (denoted by $\omega_{i}^{2}$ ) is decomposed into systematic local market risk (related to the variance $\omega_{L}^{2}$ of the local market return), additional global risk in $Z$ that is orthogonal to the local market (related to the covariance matrix $\Omega$ of $Z$ ) and specific risk $\sigma_{i}^{2}$. With this metric we are able to estimate to what extent the global market and the exchange rate risk factors add explanatory power to the domestic CAPM. Under the null-hypothesis of no pricing error the global factors should have no contribution to the total variance. The variance decomposition for a country is equal to the weighted average of all decompositions of individual firms in that country with $\left(1 / \sigma_{i}^{2}\right) /\left(\Sigma 1 / \sigma_{i}^{2}\right)$ as weights. The sample period is 1980:02-1999:06.

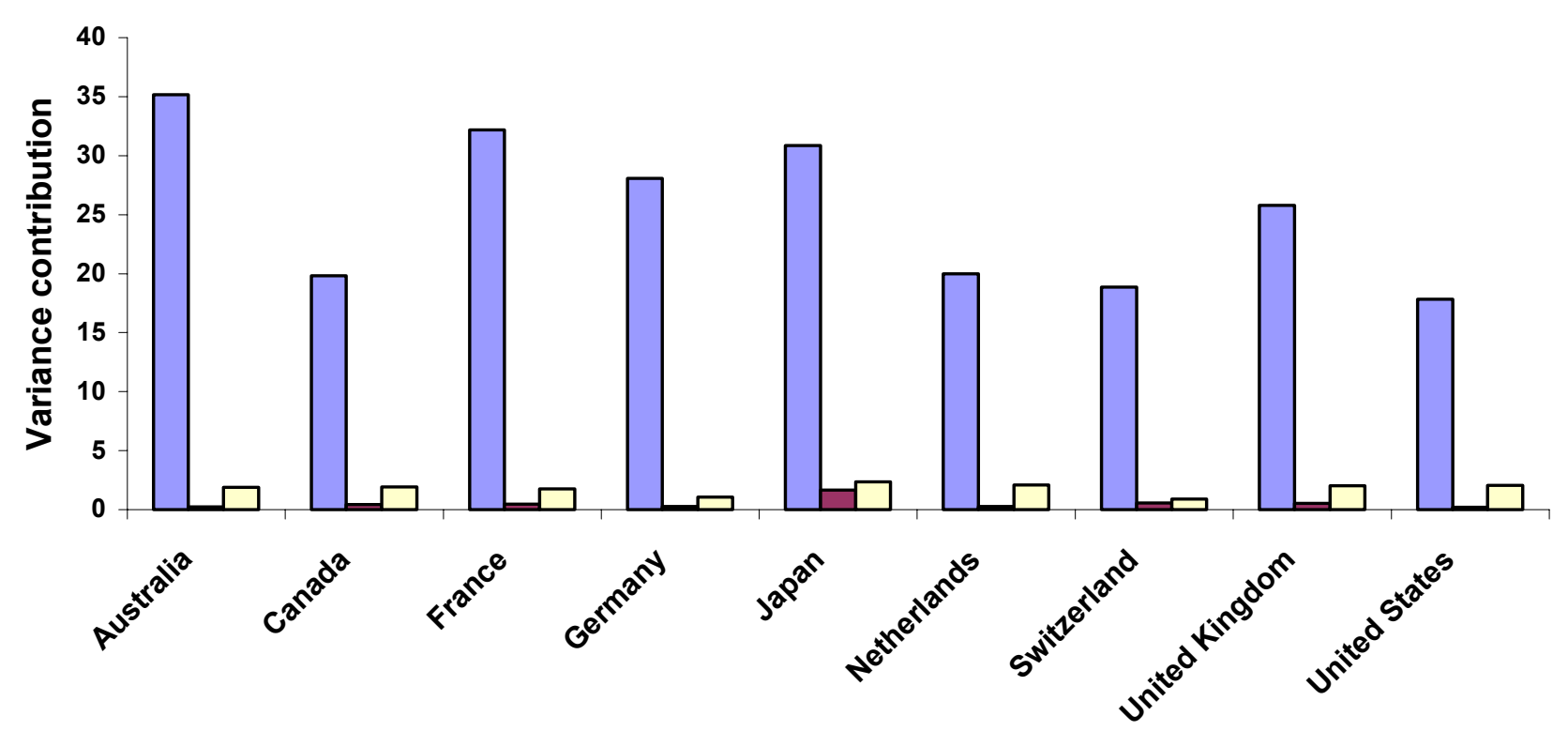




\section{Publications in the Report Series Research ${ }^{*}$ in Management}

ERIM Research Program: "Finance and Accounting"

\section{2}

A Stochastic Dominance Approach to Spanning

Thierry Post

ERS-2002-01-F\&A

Testing for Third-Order Stochastic Dominance with Diversification Possibilities

Thierry Post

ERS-2002-02-F\&A

Towards a Transaction Cost Theory of Management Control

Roland F. Speklé

ERS-2002-06-F\&A

Modeling the Conditional Covariance between Stock and Bond Returns: A Multivariate GARCH Approach

Peter De Goeij \& Wessel Marquering

ERS-2002-11-F\&A

An Empirical Comparison of Default Swap Pricing Models

Patrick Houweling \& Ton Vorst

ERS-2002-23-F\&A

Relative Distress and Return Distribution Characteristics of Japanese stocks, a Fuzzy-Probabilistic Approach Willem-Max van den Bergh, Onno Steenbeek \& Jan van den Berg

ERS-2002-29-F\&A

Does Risk Seeking Drive Asset Prices? A Stochastic Dominance Analysis of Aggregate Investor Preferences Thierry Post \& Haim Levy

ERS-2002-50-F\&A

Reinventing The Hierarchy, The Case Of The Shell Chemicals Carve-Out Michel A. van den Bogaard, Roland F. Speklé

ERS-2002-52-F\&A

A Framework For Managing A Portfolio Of Socially Responsible Investments Winfried Hallerbach, Haikun Ning, Aloy Soppe, Jaap Spronk ERS-2002-54-F\&A

The Relevance of MCDM for Financial Decisions

Winfried Hallerbach, Jaap Spronk

ERS-2002-69-F\&A

A broadband vision of the development of the DAX over time Winfried Hallerbach, Christoph Hundack, Igor Pouchkarev, Jaap Spronk ERS-2002-87-F\&A

A complete overview of the ERIM Report Series Research in Management: http://www.ers.erim.eur.nl

ERIM Research Programs:

LIS Business Processes, Logistics and Information Systems

ORG Organizing for Performance

MKT Marketing

F\&A Finance and Accounting

STR Strategy and Entrepreneurship 
Do Countries or Industries Explain Momentum in Europe?

Theo Nijman, Laurens Swinkels, Marno Verbeek

ERS-2002-91-F\&A

Measuring Credit Spread Risk: Incorporating the Tails

Rachel Campbell, Ronald Huisman

ERS-2002-95-F\&A

Option Formulas for Mean-Reverting Power Prices with Spikes

Cyriel de Jong, Ronald Huisman

ERS-2002-96-F\&A

The Cost of Capital of Cross-Listed Firms

Kees G. Koedijk, Mathijs A. van Dijk

ERS-2002-99-F\&A

Do Global Risk Factors Matter for International Cost of Capital Computations?

Kees G. Koedijk, Mathijs A. van Dijk

ERS-2002-100-F\&A

Dividing the Pie: Asymmetrically Informed Dealers and Market Transparency Mark D. Flood, Kees G. Koedijk, Mathijs A. van Dijk, Irma W. van Leeuwen

ERS-2002-101-F\&A 